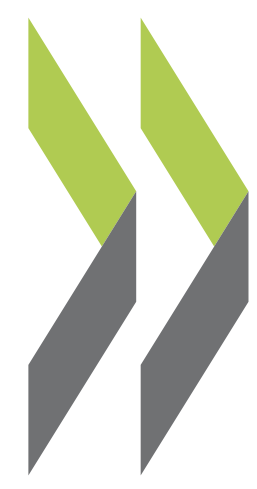

OECD Economics Department Working Papers No. 919

Explaining the Interest-RateGrowth Differential Underlying Government David Turner, Debt Dynamics 
Organisation de Coopération et de Développement Économiques

Organisation for Economic Co-operation and Development

19-Dec-2011

ECONOMICS DEPARTMENT

English text only

EXPLAINING THE INTEREST-RATE-GROWTH DIFFERENTIAL UNDERLYING GOVERNMENT DEBT DYNAMICS

ECONOMICS DEPARTMENT WORKING PAPER No. 919

By David Turner and Francesca Spinelli

All Economics Department Working Papers are available through OECD's internet website at www.oecd.org/eco/workingpapers 


\section{ABSTRACT/RÉSUMÉ}

\section{Explaining the Interest-Rate-Growth Differential Underlying Government Debt Dynamics}

The differential between the interest rate paid to service government debt and the growth rate of the economy is a key concept in assessing fiscal sustainability. Among OECD economies, this differential was unusually low for much of the last decade compared with the 1980s and the first half of the 1990s. This paper investigates the reasons behind this profile using panel estimation on 23 OECD economies. The results suggest that the fall is partly explained by lower inflation volatility associated with the adoption of monetary policy regimes which credibly target low inflation, which might be expected to continue. However, the low differential is also partly explained by factors which are likely to be reversed in the future, including very low policy rates, the "global savings glut" and the effect which the European Monetary Union had in reducing long-term interest differentials in the pre-crisis period. The differential is also likely to rise in the future because the number of countries which have debt-to-GDP ratios above a threshold at which there appears to be an effect on sovereign risk premia has risen sharply. Moreover, debt is projected to increasingly rise above this threshold in most of these countries.

JEL classification: E43; E62; H63; H68

Keywords: fiscal sustainability; government debt; interest rates; interest-rate-growth differential.

\section{$* * * * * * * * * * * * * * * * * * * * * * * * * * *$ \\ Expliquer le différentiel entre taux d'intérêt et croissance qui sous-tend la dynamique de la dette publique}

Le différentiel entre le taux d'intérêt payé sur la dette publique et le taux de croissance de l'économie est un concept clé pour évaluer la viabilité budgétaire. Parmi les économies de l’OCDE, ce différentiel a été exceptionnellement bas pendant une grande partie de la décennie passée en comparaison des années 80 et de la première moitié des années 90 . Le présent document cherche à expliquer ce profil à l'aide d'une estimation en panel réalisée sur 23 pays de l'OCDE. Les résultats semblent indiquer que la diminution de l'écart s'explique en partie par une plus faible volatilité de l'inflation associée à l'adoption de régimes de politique monétaire visant de façon crédible un taux d'inflation peu élevé, un facteur qui paraît devoir persister. Cependant, cet écart peu marqué est aussi imputable, pour partie, à des facteurs qui vont sans doute s'inverser dans l'avenir, notamment des taux directeurs très bas, l' " excédent mondial d'épargne " et l'impact de la réduction des différentiels de taux d'intérêt à long terme opérée au sein de l’Union monétaire européenne au cours de la période qui a précédé la crise. L’écart pourrait aussi se creuser dans l'avenir du fait de la forte augmentation du nombre de pays dont le ratio dette-PIB dépasse un seuil qui, apparemment, déclenche un effet sur la prime de risque souverain. De plus, la dette va sans doute dépasser de plus en plus largement ce seuil dans la plupart de ces pays.

Classification JEL : E43 ; E62, ;H63 ; H68

Mots-Clés : la viabilité budgétaire ; la dette publique ; les taux d'intérêt ; aux taux d'intérêt différentiel de croissance.

\section{Copyright OECD 2011}

Application for permission to reproduce or translate all, or part of, this material should be made to: Head of Publications Service, OECD, 2 rue André-Pascal, 75775 Paris Cedex 16, France. 
TABLE OF CONTENTS

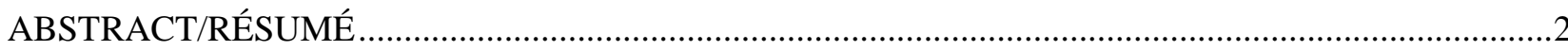

EXPLAINING THE INTEREST-RATE-GROWTH DIFFERENTIAL UNDERLYING GOVERNMENT

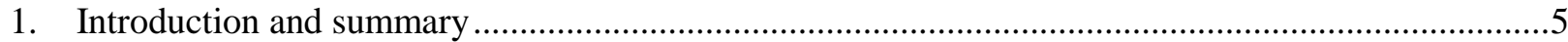

2. The importance of the interest-rate-growth differential in debt dynamics .........................................

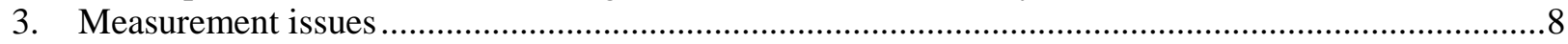

4. Possible explanations for changes in the interest-rate-growth differential .....................................10

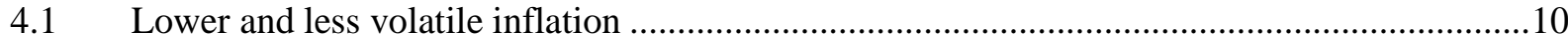

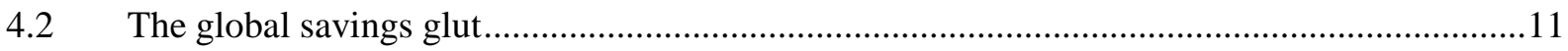

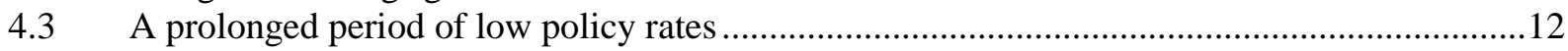

4.4 A fiscal risk premium related to government indebtedness.........................................................13

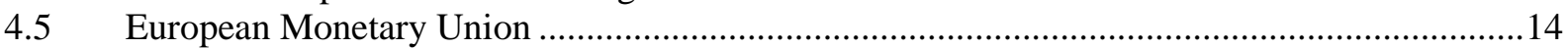

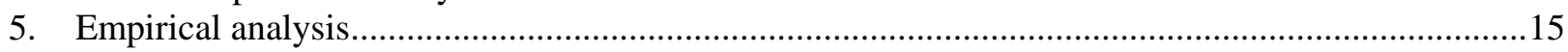

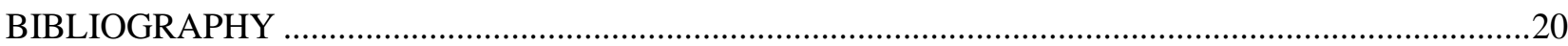

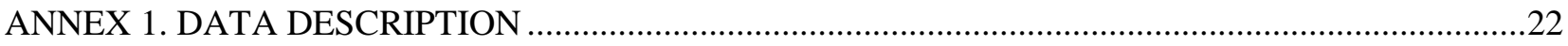

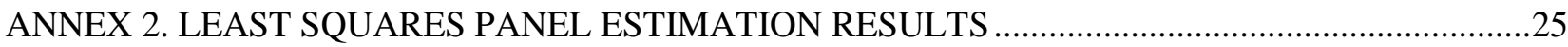

\section{Tables}

1. The interest-rate-growth differential for 23 OECD countries ..........................................................10

2. Panel regression results explaining the interest-rate-growth differential for 23 OECD countries .......17

3. Summary statistics of the explanatory variables used in the regressions .........................................18

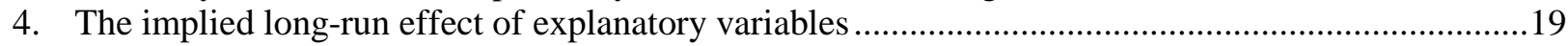

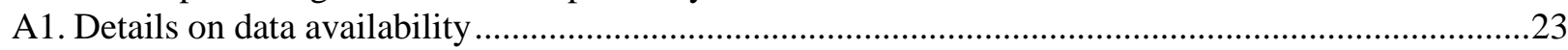

A2. List of countries composing the different aggregates considered in the empirical analysis ...............24

A3. Panel regression results explaining the interest-rate-growth differential for 23 OECD countries ......25

A4. The implied long-run effect of explanatory variables .....................................................................26

\section{Figures}

1. Sensitivity of debt projections to the interes-rate-growth differential...............................................

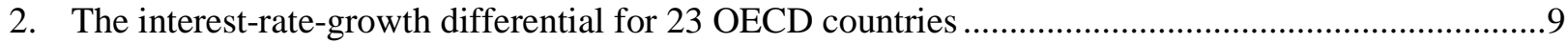

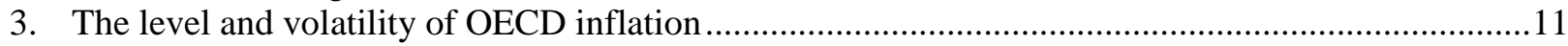

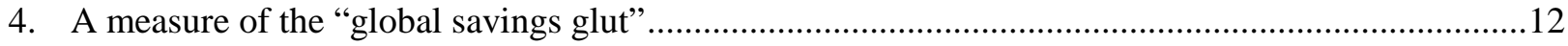

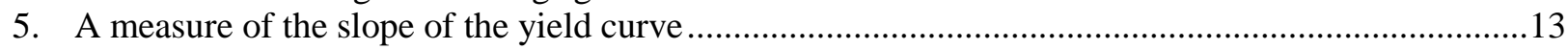

6. OECD countries for which gross government debt exceeds $75 \%$ of GDP ......................................14

7. Interest rate spreads on 10-year government bonds for selected EMU countries ...............................15

This document and any map included herein are without prejudice to the status of or sovereignty over any territory, to the delimitation of international frontiers and boundaries and to the name of any territory, city or area. 
ECO/WKP(2011)88 
ECO/WKP(2011)88

\title{
EXPLAINING THE INTEREST-RATE-GROWTH DIFFERENTIAL UNDERLYING GOVERNMENT DEBT DYNAMICS
}

\author{
by
}

David Turner and Francesca Spinelli ${ }^{1}$

\section{Introduction and summary}

1. A key issue in assessing long-run fiscal sustainability is the future trend of the differential between the interest rate paid to service government debt and the growth rate of the economy. For highly indebted countries, a change in this differential of a couple of percentage points, if sustained, could mean the difference between an explosive or a declining path for the debt-to-GDP ratio.

2. In this context, it matters a lot whether OECD countries are likely to face the low interest-rategrowth differential environment which typically prevailed over much of the pre-crisis 2000s or the much higher and less favourable differential which was typical of the 1980s and the first half of the 1990s. ${ }^{2}$ Among a group of 23 OECD countries considered in this paper the median interest-rate-growth differential fell from almost $2 \frac{1}{2}$ percentage points to about zero between these periods, with a much greater fall for those countries which initially had a larger differential. This paper attempts to evaluate the relative importance of various explanations for the fall in the differential as a guide to understanding possible future trends.

3. The main findings of the paper are as follows:

- The decline in uncertainty surrounding inflation, associated with the decline in the level and more particularly the volatility of inflation, has almost certainly contributed to a fall in the interest-rategrowth differential. The empirical work reported in this paper suggests that it might have contributed between $3 / 4$ and 1 percentage point for the typical OECD country, and by more for those countries where inflation volatility has declined by more. This change is probably the

1. The authors are members of the Macroeconomic Analysis Division of the OECD Economics Department. They would like to thank participants of the UN DESA Expert Group meeting on the World Economy (LINK Project) on 24-26 October 2011 for comments on an early presentation of this work. In addition, they would like to thank Jean-Luc Schneider, Jorgen Elmeskov, Lukasz Rawdanowicz, Yvan Guillemette, Stéphanie Guichard and Mauro Pisu for helpful comments on the paper as well as Diane Scott for help in the final document preparation. The views expressed in this paper are those of the authors and do not necessarily represent those of the OECD or its member countries.

2. The focus of this paper is on explaining the interest-rate-growth differential of OECD economies. The corresponding differential for developing countries is typically much lower, and usually negative, which mainly appears to be the consequence of financial repression (Escolano et al., 2011 and IMF, 2011a). 
consequence of a general move in the use of monetary policy towards a more credible targeting of inflation. To the extent that inflation expectations remain anchored in the future these gains might be expected to persist.

- On the other hand, other factors behind the low differential over the last decade are unlikely to persist over the longer term and their reversal is likely to result in an increase in the differential:

- Policy rates and short-term interest rates were unusually low for an unusually long time over the last decade, partially in response to fears about the severity of the downturn and the risks of deflation following the sharp fall in equity prices at the end of the 1990s. This, by creating expectations of future low interest rates, almost certainly dragged down long-term interest rates. In the wake of the financial crisis, policy rates in many countries have been further cut too extremely low levels. Although this situation may continue for a few (or even many) years, over the longer run as policy rates normalise this is likely to push up the interest-rategrowth differential. Estimates in this paper suggest that for a typical OECD country this will imply a rise in the interest-rate-growth differential by around 1 to $1 \frac{11 / 4}{4}$ percentage points.

- This paper provides some tentative empirical support for the effect of a "Global Savings Glut" originating from Asian emerging markets and oil exporters with an estimated effect of reducing the interest-rate-growth differential during the 2000 s by around $1 \frac{1}{4}$ to $1 \frac{1}{2}$ percentage points. Such a global savings-investment imbalance is unlikely to persist indefinitely. Indeed, there are arguments to suggest that future trends in global savings and investment are more likely to put upward pressure on global interest rates and hence raise the interest-rate-growth differential (Dobbs et al., 2010).

- One factor which is likely to exert a much larger positive influence on the interest-rate-growth differential over the future is higher fiscal sovereign risk premia associated with increased government indebtedness, which for many countries has increased substantially in the wake of the crisis. Some evidence is found in support of a threshold effect, whereby each percentage point increase in the gross government debt-to-GDP ratio above 75\% of GDP leads to an increase in the differential of 4 basis points. According to recent OECD projections (OECD, 2011) there are likely to be 15 OECD countries with debt ratios exceeding this threshold compared with just six countries immediately prior to the crisis.

- Relative to the pre-crisis period, the change in the interest-rate-growth differential may be particularly large for some euro area countries, as it is clear that over the pre-crisis period the introduction of European Monetary Union led to a marked convergence of long-term interest rates among member countries so masking the effect of individual country characteristics such as indebtedness. However the current euro area sovereign debt crisis is resolved, it seems likely that fundamentals will play a more important role in determining long-term interest rates of individual countries within EMU in the future.

4. The remainder of the paper is organised as follows: the following section explains the importance of the interest-rate-growth differential in debt dynamics; section 3 considers various measurement issues and examines past trends in the differential for OECD countries; section 4 outlines and describes the possible explanations for past trends in the differential; section 5 attempts to discriminate between these explanations using panel estimations on a large number of OECD countries. 


\section{The importance of the interest-rate-growth differential in debt dynamics}

5. The interest-rate-growth differential is essential to understanding long-run fiscal sustainability; higher interest rates imply higher interest payments to service government debt so adversely influencing debt dynamics, whereas higher nominal GDP growth will tend to lower the debt-to-GDP ratio by increasing the denominator. More formally, the importance of the interest-rate-growth differential can be seen from the government budget identity, ${ }^{3}$ whereby the change in the net government debt-to-GDP ratio (d) is explained by the primary deficit ratio (-pb) plus net interest rates payments on the previous period's debt, where $i_{t}$ is the effective interest rate paid on net government debt, so that approximately:

$$
\Delta d_{t}=-p b_{t}+\left(i_{t}-g_{t}\right) d_{t-1}
$$

where $\mathrm{g}_{t}$ is the nominal GDP growth rate. Thus, for a given primary balance and initial net debt ratio, the rate of increase in the debt-to-GDP ratio is positively related to the interest-rate-growth differential.

6. In order to illustrate the importance of the interest-rate-growth differential in long-term fiscal projections, the sensitivity of recently published OECD fiscal projections to alternative assumptions regarding this differential are considered. The long-term projections published in June 2011 (OECD, 2011) are based on the stylised assumption that beyond 2012 gradual fiscal consolidation, equal to an improvement in the underlying primary balance of $1 / 2$ percentage point of GDP each year, is undertaken until the debt-to-GDP ratio is stabilised. The United States is one of only two OECD countries for which the stylised gradual fiscal consolidation would be insufficient to stabilise the government debt-to-GDP ratio by 2026, with gross general government debt reaching nearly $150 \%$ of GDP, although the rate of increase in the debt ratio is clearly diminishing (Figure 1). The importance of the interest-rate-growth differential in debt dynamics, particularly for a highly-indebted country, is illustrated by the substantial difference in two variant simulations in which the differential is alternatively increased and then decreased by 2 percentage points relative to this baseline, assuming that the primary balance remains the same as in the baseline. ${ }^{4}$

7. Moreover, these calculations could underestimate the effect of the differential on debt projections for at least two reasons:

- $\quad$ The shock to the differential is applied ex post, whereas if applied ex ante there might be reasons to expect further changes to the differential which re-enforce the effect of the original shock; for example, if debt begins to rise as a consequence of a higher differential then fiscal risk premium on debt might be expected to rise; also at higher levels of debt there is some empirical evidence to suggest that there may be some adverse effect on real growth rates (Reinhart and Rogoff, 2010).

- These stylised fiscal projections are based on the assumption that primary public expenditure remains a stable share of GDP. However, if the differential falls as a result of faster growth it is likely that some components of public expenditure, such as infrastructure expenditure, would rise less than proportionately, which in turn would imply a more rapid reduction in debt.

3. This ignores stock-flow adjustments which have been particularly important over the crisis period, see IMF, 2011b.

4. The baseline projection is consistent with a rise in the interest-rate-growth differential to just under 2 percentage points by 2026. The lower debt path would be consistent with an interest-rate-growth differential of around zero percentage points which is similar to that experienced by the United States over the last decade, whereas the high debt path would be consistent with a differential rising to about 4 percentage points. 
Figure 1. Sensitivity of debt projections to the interest-rate-growth differential

Gross government debt of Unites States as percentage of GDP

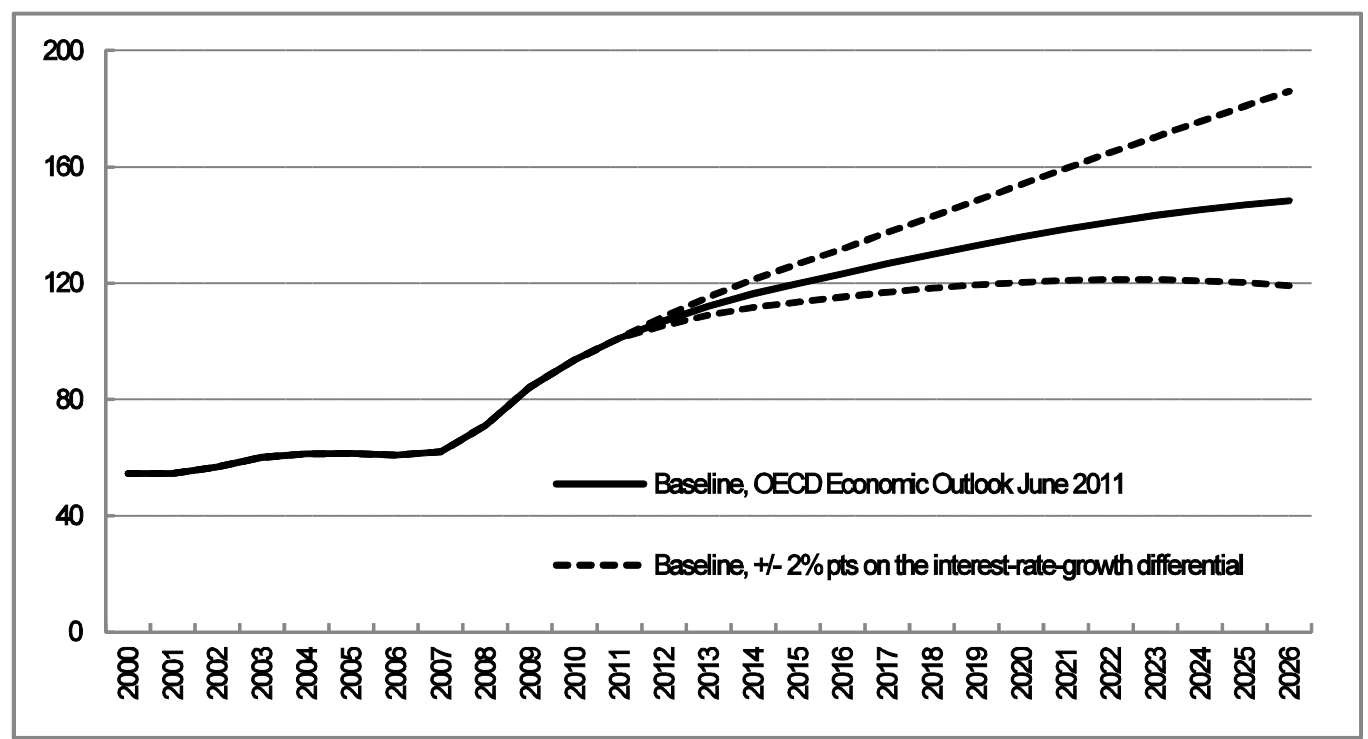

Source: OECD Economic Outlook June 2011 and OECD calculations.

\section{Measurement issues}

8. In analysing historical trends, the interest-rate-growth differential is here defined differently from how it appears in the budget identity described in [1] above. This is both to improve cross-country comparability, which is important when undertaking panel regressions, and to provide a better trend measure which abstracts from volatility, particularly that associated with the cycle, thus:

- Nominal potential GDP growth is used in place of actual GDP growth in order to reduce the volatility associated with the business cycle given that the focus here is on long-term fiscal sustainability. The estimates of potential output which are used are those described in OECD (2011) and are intended to measure the trend level of output which can be sustained without inflationary pressure.

- The interest rate that is used in the analysis here is that on 10-year government bonds which differs from the concept of the implicit interest rate on net government debt used in the budget identity [1] in a number of ways:

- The interest rate in the budget identity is the implicit net interest rate paid on net debt and so takes into account the interest receipts earned on government asset holdings. Nevertheless, the empirical analysis here focuses on the rates on 10-year government bonds because there is great heterogeneity in the size and composition of government assets holdings across countries.

- The interest rate in the budget identity is the average implicit interest rate paid on all debt which will differ from the interest rate on new issues of government debt. Thus, for example, after a prolonged period when long-term interest rates have been unusually low for a long period (perhaps for example because short-term policy rates have been low for cyclical reasons) but have recently begun to rise, then the average interest rate paid on gross 
government debt will be lower than the rate on new bond issues. However, the latter will provide a more timely indicator of the future trends in the cost of government financing.

- The interest rate which is used in the analysis is that on 10-year government bonds which will differ from even the rate of new bonds issues if these are issued at different maturities. An argument for using the former in the analysis is that it is both simpler to implement and will abstract from differences across countries regarding the maturity structure of new bond issues which may well be temporary.

- Finally, using a measure of the implicit rate on net government debt in regression analysis is ruled out for many countries because when net government debt (the denominator in any calculation of the implicit rate) becomes very low the implicit rate can easily jump to absurd levels.

9. Based on the definitions described above (see Annex 1 for further details of the data), the interest-rate-growth differential for 23 OECD countries, for which a long time series of consistent data is available, shows a marked fall from its median level in the 1980s and first half of the 1990s of typically about 2 $1 / 2$ percentage points to close to zero during the pre-crisis 2000s (Figure 2 and Table 1). Moreover, there are many countries (e.g. Australia, Canada, Denmark, Spain, Ireland and Norway) where the interest rate-growth-differential fell by 4 percentage points or more between these two periods. Subsequent sections consider the possible reasons for these changes as a basis for considering how the differential might evolve in the future.

Figure 2. The interest-rate-growth differential for 23 OECD countries

\section{Percentage points}

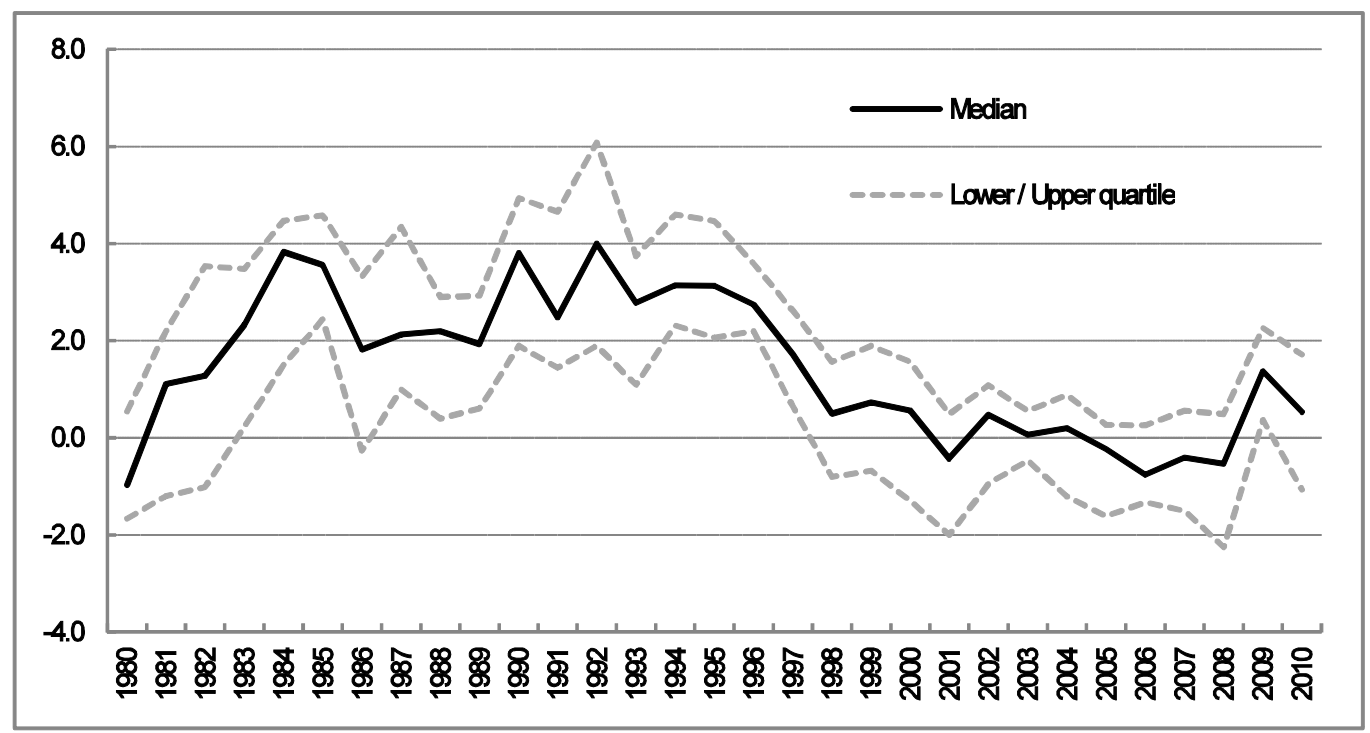

Source: OECD Economic Outlook June 2011 and OECD calculations, for country coverage see notes to Table 1 and Annex 1 for further details. 
Table 1. The interest-rate-growth differential for 23 OECD countries

\begin{tabular}{|c|c|c|c|c|}
\hline & $1980-95$ & 1996-99 & $2000-08$ & 2010 \\
\hline \multicolumn{5}{|l|}{ G7 countries } \\
\hline Upper quartile & 3.22 & 2.42 & 1.46 & 1.56 \\
\hline Median & 2.32 & 1.65 & 0.42 & 0.95 \\
\hline Lower quartile & 1.28 & 0.92 & -0.19 & 0.17 \\
\hline \multicolumn{5}{|c|}{23 OECD countries ${ }^{1}$} \\
\hline Upper quartile & 3.80 & 2.42 & 0.68 & 1.72 \\
\hline Median & 2.41 & 1.42 & -0.12 & 0.53 \\
\hline Lower quartile & 0.79 & 0.34 & -1.40 & -1.07 \\
\hline \multicolumn{5}{|c|}{ Selected EMU countries ${ }^{2}$} \\
\hline Upper quartile & 3.70 & 2.41 & 0.71 & 3.67 \\
\hline Median & 2.64 & 0.99 & -0.11 & 1.34 \\
\hline Lower quartile & 1.06 & -0.12 & -1.49 & 0.86 \\
\hline
\end{tabular}

1. Australia, Austria, Belgium, Canada, Denmark, Finland, France, Germany, Greece, Iceland, Ireland, Italy, Japan, Korea, the Netherlands, New Zealand, Norway, Portugal, Spain, Sweden, Switzerland, United Kingdom, United States.

2. Austria, Belgium, Finland, France, Germany, Greece, Ireland, Italy, Netherlands, Portugal, Spain.

Source: OECD Economic Outlook, June 2011 and OECD calculations. See Annex 1 for further details.

\section{Possible explanations for changes in the interest-rate-growth differential}

10. This section discusses a range of potential explanations for the OECD-wide fall in the interestrate-growth differential before attempting to distinguish between them empirically in the following section.

\subsection{Lower and less volatile inflation}

11. There is some evidence to suggest that inflation uncertainty is an important component of bond risk premia; certainly the decline in the interest-rate-growth differential broadly corresponds with the decline in both level and volatility of OECD inflation (Figure 3). In addition, there is evidence to suggest that the largest reductions in term premia occurred in countries that made radical changes in their monetary policy frameworks, such as introducing inflation targets and increasing the independence of their central banks (Wright, 2011). ${ }^{5}$

5. The sharp drop in forward rates in the United Kingdom on the day the Bank of England was granted operational independence, is also cited as further evidence of this effect (Wright, 2011). 
Figure 3. The level and volatility of OECD inflation

Change in the OECD-wide GDP deflator, percentage points

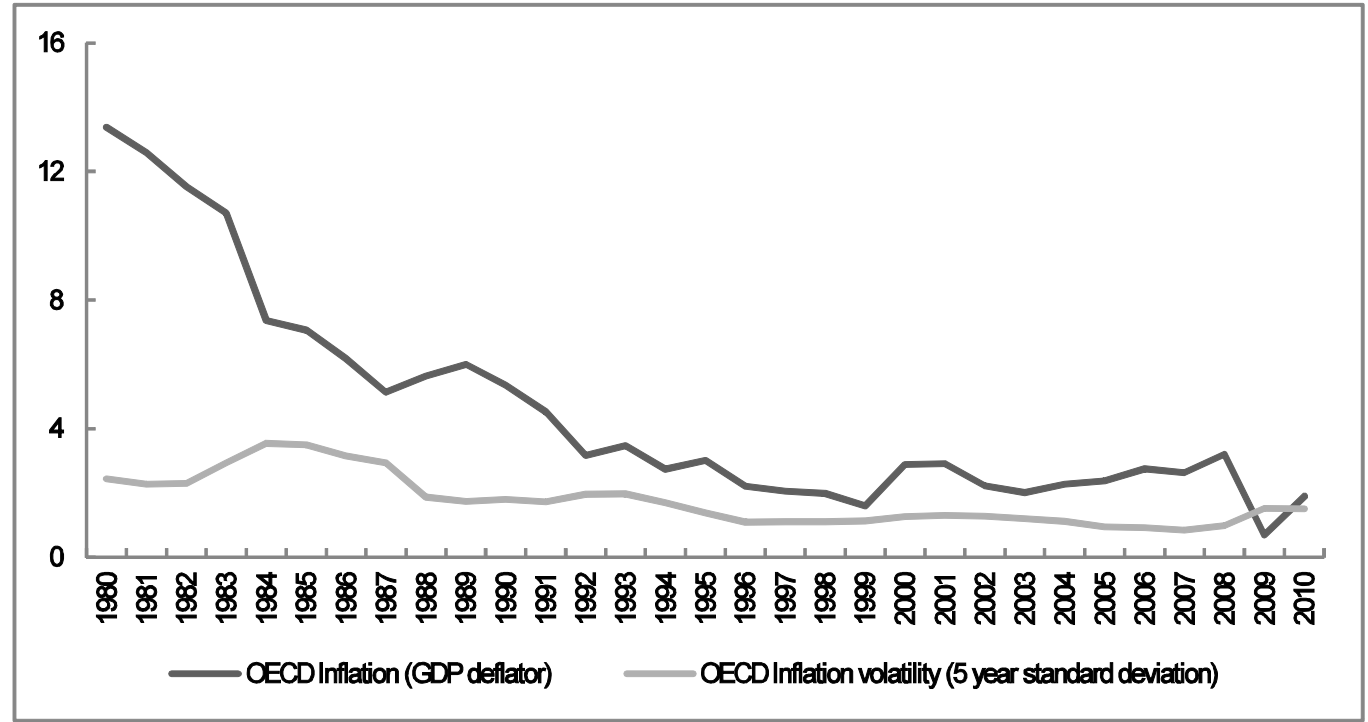

Source: OECD Economic Outlook June 2011 and OECD calculations. For country coverage see notes to Table 1 and see Annex 1 for further details.

\subsection{The global savings glut}

12. According to the "global savings glut" hypothesis (Bernanke, 2005 and 2007), increased capital inflows to the United States from countries in which desired saving greatly exceeded desired investment -- particularly Asian emerging markets and non-OECD oil exporters -- were an important reason why longterm interest rates were lower than expected in the pre-crisis 2000s. Although the argument was originally applied to the United States, in principle it seems likely that it might also apply more generally to the advanced OECD economies.

13. A crude measure of the ex ante imbalance between global savings and investment is the ex post current account surplus of the Asian emerging markets and oil exporters expressed as percentage of world GDP (Figure 4) which is used here in the subsequent empirical analysis. There will, of course, always be some countries running a current account surplus so taking a subset of these and referring to it as a measure of a "global savings glut" is admittedly crude. Nevertheless, these countries are singled out here because they ran up large current account surpluses so rapidly -- because of massive structural reform, fiscal adjustment or swings in commodity prices -- that there was no possibility to easily absorb the additional savings in domestic investment opportunities. 
Figure 4. A measure of the "global savings glut"

Combined current account surpluses of Asian emerging markets and oil exporters, as a percentage of world GDP

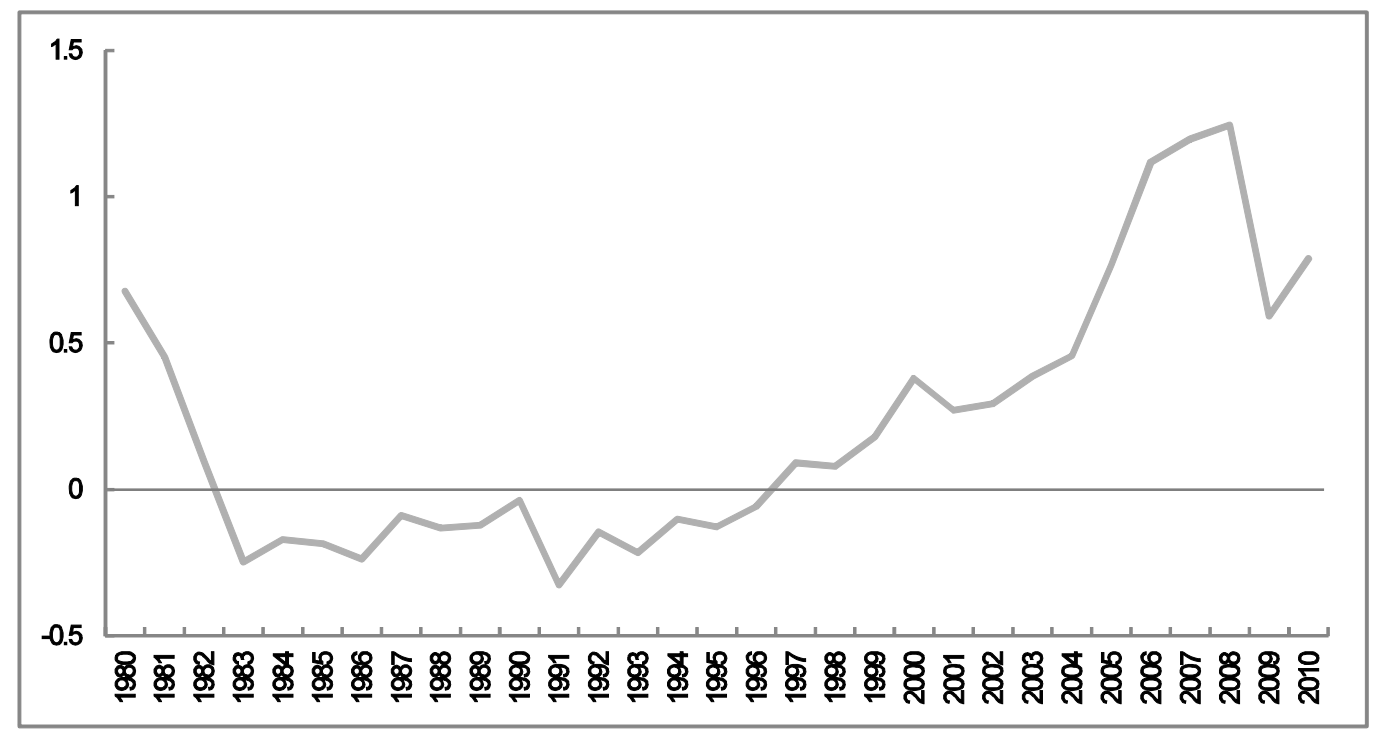

Source: International Monetary Fund, World Economic Outlook Database, September 2011. Further details in Annex 1.

\subsection{A prolonged period of low policy rates}

14. If long-term interest rates are considered as a forward convolution of expected short-term interest rates plus term premia, it follows that large deviations of short-term rates which are expected to persist over a period of many years will also pull long-term interest rates away from their more fundamental levels. Monetary policy exerts a powerful influence on short-term market interest rates. In particular, policy rates have been unusually low for an unusually long time over much of the last decade, in response firstly to fears about the severity of the downturn and the risks of deflation following the sharp fall in equity prices at the end of the 1990s and more recently in response to the financial crisis (Figure 5). This, by creating expectations of future low interest rates, almost certainly dragged down long-term interest rates. Thus, a prolonged period of exceptionally low (or high) policy rates would be expected to lower (raise) long-term interest rates contemporaneously. 
Figure 5. A measure of the slope of the yield curve

Difference between short and long-term interest rates, average across country groups, percentage points

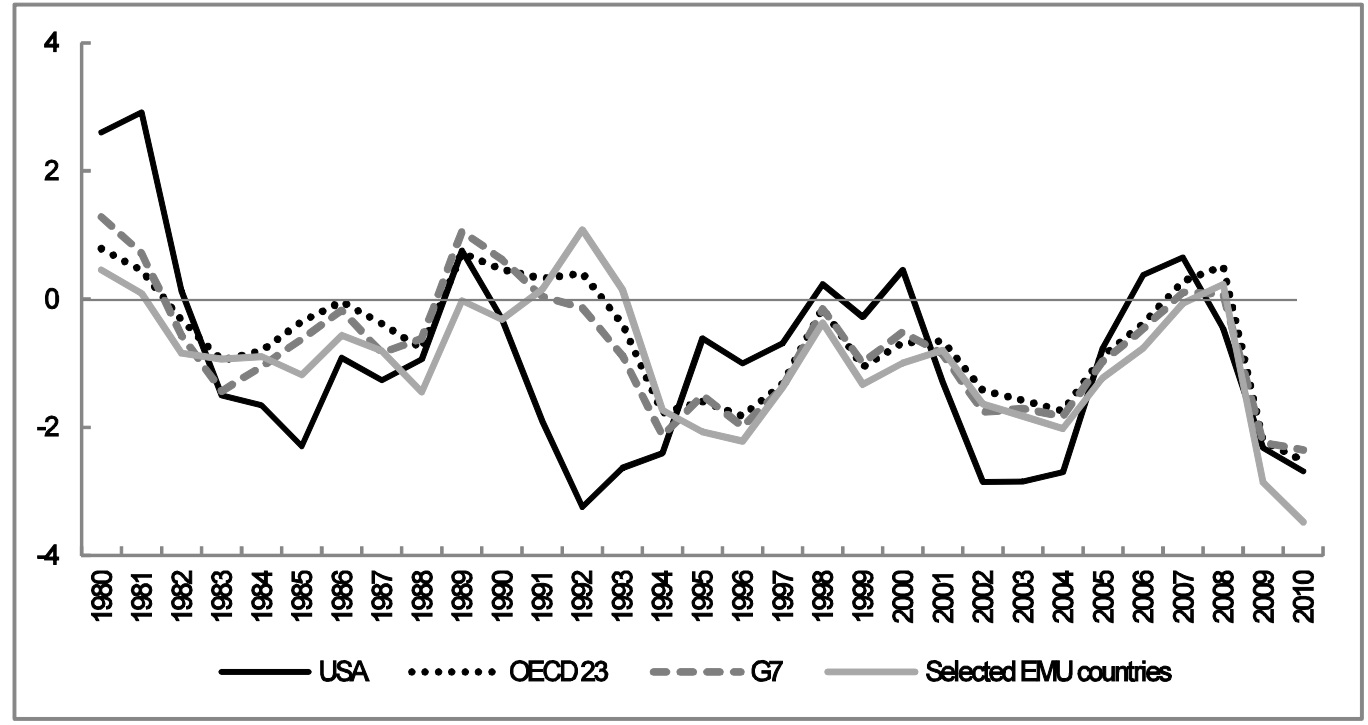

Note: Short-term interest rates are the rate on 3-month Treasury bills (or similar) and long-term rates the interest rate on 10-year government bonds.

Source: OECD Economic Outlook June 2011 and OECD calculations. See Annex 1 for further details.

\subsection{A fiscal risk premium related to government indebtedness}

15. There is a large and controversial empirical literature that examines the impact of public deficits and debt on long-term government bond yields. ${ }^{6}$ Drawing on this literature, an assumption which has been adopted for the purpose of recent long-term OECD projections is that when gross government indebtedness passes a threshold of $75 \%$ of GDP then long-term interest rates increase by 4 basis points for every additional percentage point increase in the government debt-to-GDP ratio -- an assumption consistent with the findings of Égert (2010) and Laubach (2009). ${ }^{7}$ Although such thresholds are inevitably somewhat arbitrary, it is clear that the number of countries with debt-to-GDP ratios above this ratio has risen substantially in the aftermath of the recent crisis (Figure 6).

6. $\quad$ See Box 4.5 in OECD (2010) for a selective survey.

7. Égert (2010) finds that the difference between short-term and long-term interest rates appear to be a nonlinear function of public debt for the G7 countries (excluding Japan) in recent years. The estimation results indicate a 4 basis point increase in long-term rates relative to short-term rates for each percentage point of GDP in public debt above 76\%. Laubach (2009) focuses on the United States and finds that long-term yields increase about 25 basis points per percentage point increase in the projected deficit-to-GDP ratio, and 3 to 4 basis points per percentage point increase in the debt-to-GDP ratio. 
Figure 6. OECD countries for which gross government debt exceeds $75 \%$ of GDP

Percentage of GDP

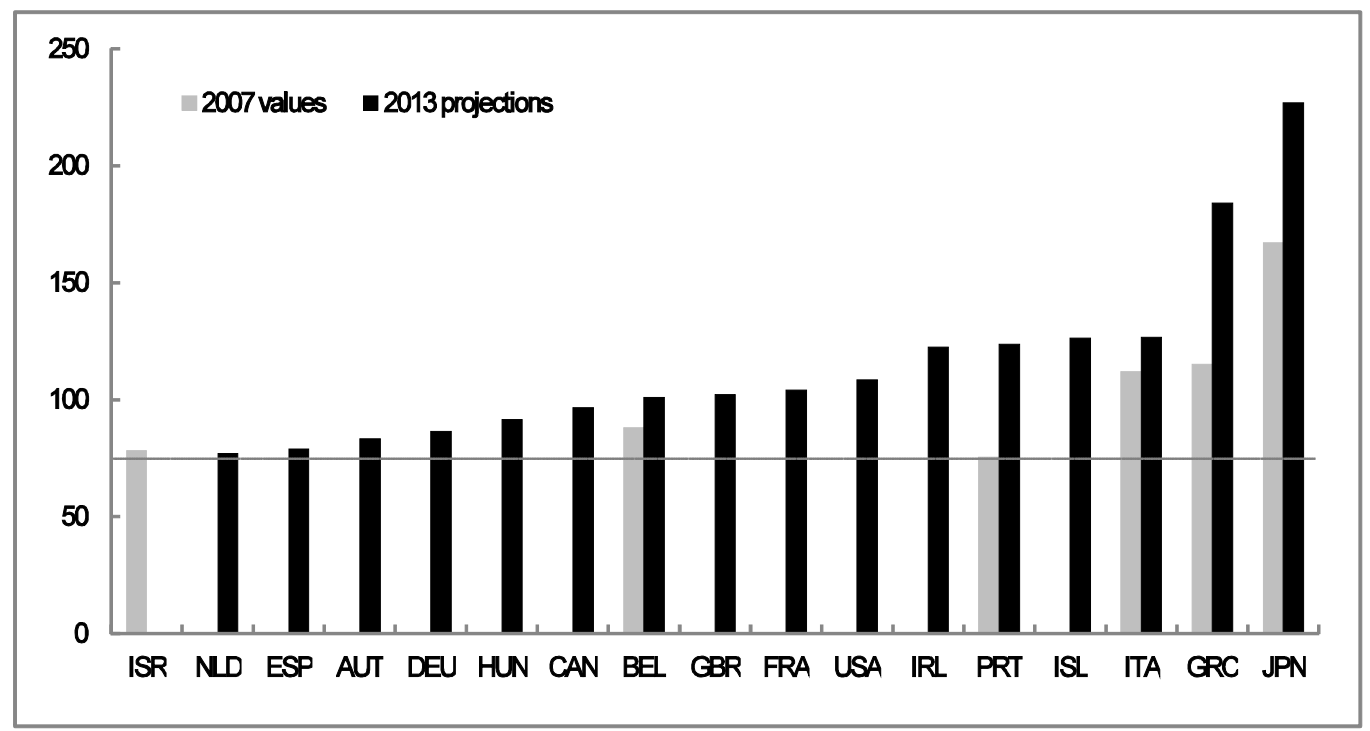

Note: Although reported in the chart, Hungary (HUN) and Israel (ISR) have not been included in the empirical analysis.

Source: OECD Economic Outlook November 2011 and OECD calculations.

16. Nevertheless, it is clear from the recent experience of euro area countries that concerns about government indebtedness vary not only with the magnitude of indebtedness, but with the general perception of risk in financial markets (see for example Haugh et al., 2009), so that identifying such effects in time series analysis over long estimation periods is inherently difficult.

\subsection{European Monetary Union}

17. The European Monetary Union (EMU) led to narrowing of spreads among member countries (Figure 7) probably because indebted countries did not have the option to tackle fiscal problems through a lax monetary policy, higher inflation and currency depreciation and default was thought unlikely. Although the euro did not come into creation until 1999 (with notes and coins only introduced in January 2002) it is clear that the anticipation of EMU was having an effect on spreads in the late 1990s. For the purposes of the empirical work the possible effect of EMU on the interest-rate-growth differential of member countries is considered from 1998 onwards through the inclusion of time dummy variable. ${ }^{8}$ In the wake of the 2008-09 financial crisis as fiscal positions in many countries have dramatically worsened, spreads have widened with growing concerns about the adequacy of institutional arrangements for a lender-of-last resort to heavily indebted member countries which come under extreme pressure from financial markets. For this reason the EMU time dummy is not extended beyond 2008.

8. In May 1998 the eleven initial countries that would initially participate in EMU were selected, and in June 1998 the ECB was created. 
Figure 7. Interest rate spreads on 10-year government bonds for selected EMU countries

Difference in rate compared with German bonds, percentage points

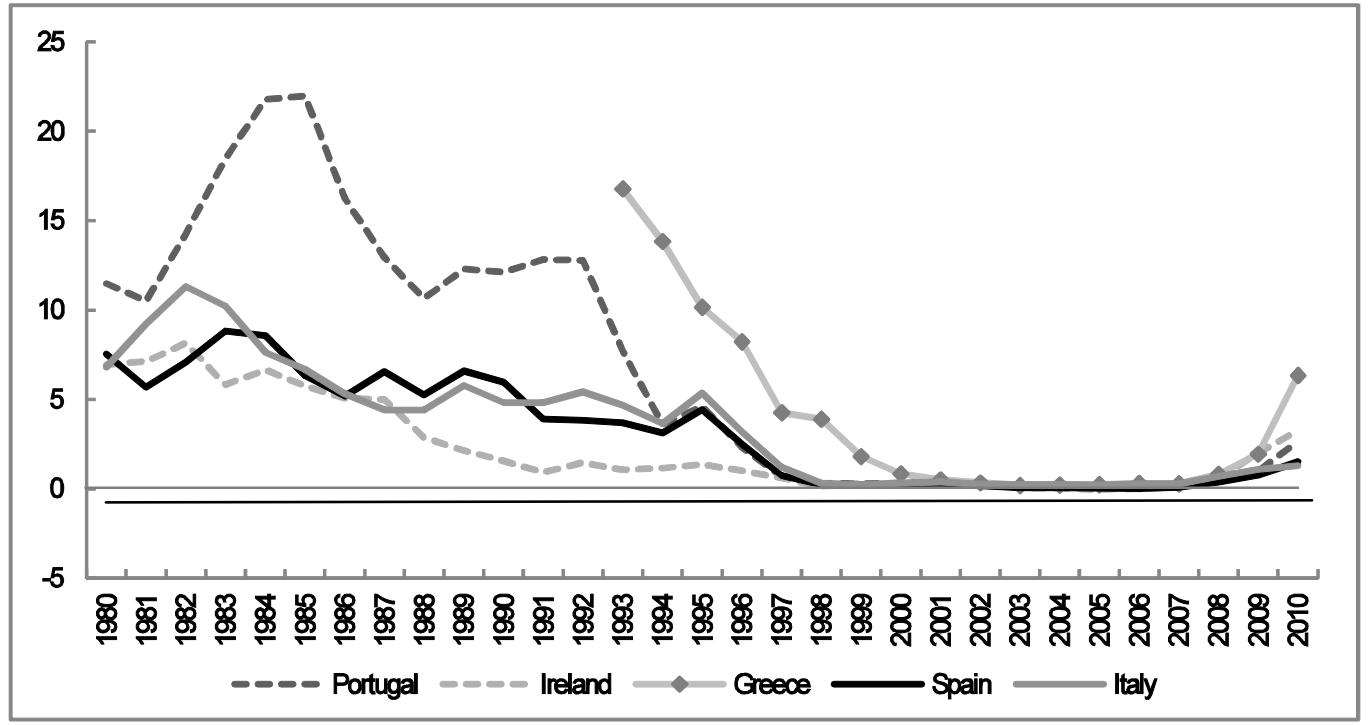

Source: OECD Economic Outlook June 2011 and OECD calculations.

\section{Empirical analysis}

18. In order to assess the relative importance of the various explanations discussed in the previous section, annual panel regressions explaining the interest-rate-growth differential (as defined in section 3 above) are run for 23 OECD countries for which a long time span of data is available, mostly covering the period 1980-2010. ${ }^{9}$ A potential problem in estimation is that the inclusion of a lagged dependent variable may lead to biased estimates (Nickell, 1981), although because the time dimension here is relatively large (exceeding 30), the extent of the bias is likely to be small (see for example, Baltagi and Griffin, 1997). Nevertheless, in order to correct for any possible bias, the bias corrected least squares dummy variable estimator for dynamic unbalanced panel data models proposed by Bruno (2005) has been applied. ${ }^{10}$

19. The simplest panel regression, equation (1) in Table 2, explains the interest-rate-growth differential in terms of its own lag, a 5-year standard deviation of inflation measured according to the GDP deflator and the lagged difference between a 3-month interest rate (a Treasury bill rate or similar) and the 10-year government bond rate (see Table 3 for summary statistics). ${ }^{11}$ The estimated coefficients are all statistically significant and with the expected signs. They imply that a fall in the standard deviation of inflation by 1 percentage point, which is about the typical reduction observed between the periods 1980-95 and 2000-08, will eventually lead to a decline in the interest-rate-growth differential of just over a percentage point (Table 4).

9. The panel is unbalanced, because there are some countries for which data is not complete over the full sample period. Further details are given in Annex 1.

10. Indeed, simple least squares estimation with country fixed effects (with no correction for the presence of a lagged dependent variable), gives similar results as reported in Annex 2, to those reported in the main body of the paper based on the estimator proposed by Bruno (2005).

11. The results are robust to using different measures of inflation, such as ones based on the Consumer Price Index or Private Consumption Expenditure Deflator. For further details on the variables used in the estimation see Annex 1. 
20. A difference between short and long-term interest rates of 1 percentage point will depress the interest-rate-growth differential by 0.6 percentage points. This implies that on average the unusually low policy rates in the pre-crisis 2000's may have reduced the interest-rate-growth differential by just under $1 / 2$ percentage point relative to the period 1980-95. Given the further steepening of the yield curve since the advent of the crisis, it also implies that a normalisation of the yield curve from conditions prevailing in 2010 might be expected to increase the interest-rate-growth differential by around a percentage point. ${ }^{12}$

21. A proxy measure of the global saving glut is taken to be the sum of current account surpluses in Asian emerging markets and non-OECD oil exporters (see section 4.2 and Annex 1). When this variable is added, equation 2 in Table 2, the coefficients on the existing explanatory variables remain statistically significant, but the size of the effect from the inflation variability variable falls [comparing equations (1) and (2) in both Table 2 and Table 4]. The new variable has the expected sign and is statistically significant, and implies that the emergence of the global savings glut in the 2000s reduced the interest-rate-growth differential by about 11/4 percentage points across all OECD countries. The global savings glut hypothesis, as originally formulated by Bernanke (2005), particularly focussed on the effect on US interest rates, however variant equations (not reported here) did not find a statistically significantly larger effect on the United States compared with other OECD countries. As previously mentioned in section 4.2, the global savings glut variable is inevitably a crude proxy measure because it is not really possible to measure an $e x$ ante global savings-investment imbalance. An alternative explanation of the significance of this variable is that it is picking up some other effect which differentiated the 2000s from earlier decades, for example it might be picking up a general under-pricing of risk in financial markets.

22. Rather than conduct an exhaustive search (or fishing expedition) of different ways in which government indebtedness might impact on the differential, it was decided to include it in a form which would most easily allow the effect of debt on interest rates assumed in recent OECD Economic Outlooks to be tested. Thus, the extent to which general government debt-to-GDP ratio exceeds $75 \%$ was included as an explanatory variable (for those countries/periods in which the debt ratio was less than $75 \%$ the variable takes the value of zero), see equation (3) in Table 2 . This debt variable is statistically significant and implies a marginal effect such that each percentage point in debt in excess of $75 \%$ eventually raises the interest-rate-growth differential by 4 basis points, which coincidentally is what is assumed in recent Economic Outlook exercises. However, the fragility of this result is underlined by the inclusion of an additional variable, measured as the product of the same debt variable and a post-crisis dummy variable, see equation (4) in Table 2, which implies that the pre-crisis effect of debt is much weaker and statistically insignificant and the post-crisis debt effect much larger; thus pre-crisis, a percentage point increase in the debt ratio above the 75\% threshold implied an increase in the differential of 3 basis points, whereas postcrisis it implies an increase of 8 basis points.

23. A final pair of regressions explore the effect that European Monetary Union had on the interestrate-growth differential (Table 2, equations 5 and 6). Given the evidence that EMU led to a striking convergence of long-term interest rates (Figure 8) the inclusion of lagged variable in the differential between German long-term interest rates and own-country growth for all EMU countries in the sample over the period 1998 to 2008 was included. The long-run coefficient on this new variable is close to unity, implying that German long rates were a powerful attractor for long-term interest rates in other EMU countries over the period 1998-2008. The fit of this equation is included by excluding the influence of the inflation variability, global savings glut and debt variables for non-German EMU countries over the period 1998-2008. Arguably the influence of lower inflation variability and the global savings glut variable is already included in German long-term interest rates and so if this is an attractor for other EMU long-term rates there is no need to include the effect separately. The improved significance of the debt variable, when

12. This calculation assumes that in the absence of cyclical influences, long-term interest rates would be expected to exceed short-term rates by about $1 \frac{1}{2}$ percentage point because of a term premium. 
EMU countries are excluded for the period 1998-2008, further suggests that effect of government indebtedness on fiscal risk premia was suspended for these countries over the period 1998-2008, an effect which is more difficult to rationalise.

24. Also of interest is that the long-run effect of most of the explanatory variables for non-EMU countries is little affected by these EMU variant equations (Table 4), with the possible exception of the effect of the global savings glut variable which has slightly larger and more statistically significant effect.

Table 2. Panel regression results explaining the interest-rate-growth differential for 23 OECD countries Sample 1980-2010, Dependent variable (irl - g), bias-corrected LSDV estimates ${ }^{1}$

\begin{tabular}{|c|c|c|c|c|c|c|c|c|c|c|c|c|}
\hline & (1) & & (2) & & (3) & & (4) & & (5) & & (6) & \\
\hline (irl-g)-1 & 0.6898 & $* * *$ & 0.6440 & $* * *$ & 0.6695 & $* * \star$ & 0.6720 & $* * *$ & 0.6026 & $* * *$ & 0.5790 & $* * *$ \\
\hline $\mathrm{SD}_{5}(\pi)$ & 0.3683 & $* * *$ & 0.3178 & $* * *$ & 0.2848 & $* * *$ & 0.2751 & $* *$ & 0.2582 & ** & 0.3731 & $* \star *$ \\
\hline (irs -irl)-.1 & 0.1740 & $* * *$ & 0.1480 & $* \star *$ & 0.2127 & $* * *$ & 0.2113 & $* \star *$ & 0.2009 & 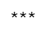 & 0.1837 & $* \star *$ \\
\hline Global Savings Glut & - & & -0.5602 & $* \star *$ & -0.5113 & ** & -0.5423 & $* * *$ & -0.7007 & *** & -0.8906 & $* \star *$ \\
\hline Debt $>75$ & - & & - & & 0.0134 & * & 0.0082 & & 0.0137 & * & 0.0180 & $* * *$ \\
\hline Dum2009-10 * Debt >75 & - & & - & & - & & 0.0175 & * & - & & - & \\
\hline$\left(\mathrm{ir} \mathrm{l}^{\mathrm{DEU}}-\mathrm{g}\right)_{-1}$ & - & & - & & - & & - & & 0.4333 & $* \star *$ & 0.4382 & *** \\
\hline Number of observations & 641 & & 641 & & 592 & & 592 & & 592 & & 592 & \\
\hline Average number of time periods & 28 & & 28 & & 26 & & 26 & & 26 & & 26 & \\
\hline Number of Countries & 23 & & 23 & & 23 & & 23 & & 23 & & 23 & \\
\hline
\end{tabular}

Notes:

Key to variables: $($ irl $-g)=$ the interest-growth-differential, see also Table1 and section 3; $\mathrm{SD}_{5}(\pi)=5$-year standard deviation of inflation, where the latter is measured by the change in the GDP deflator; (irs-irl) = the slope of the yield curve measured as the difference between short- and long-term interest rates, see also section 4.3 and Figure 5; 'Global Savings Glut' = Combined current account surpluses of Asian emerging economies and oil exporting countries, see also section 4.2 and Figure 4; Debt $>75=$ zero if gross government debt as a share of GDP is less than $75 \%$, otherwise is equal to the excess of this share above $75 \%$; Dum $200910=$ a dummy variable taking the value unity in the post-crisis years of 2009 and 2010 and zero elsewhere; (irl ${ }^{\mathrm{DEU}}-\mathrm{g}$ ) is the difference between German long-term interest rates and own-country growth. For further details of all variables used see Annex 1.

For equation (6), the explanatory variables $\mathrm{SD}_{5}(\pi)$, 'Global Savings Glut' and Debt $>75$ are all multiplied by a dummy variable defined as (1-EMU), where EMU is a dummy variable taking the value of unity for all non-German EMU countries over the period 1998-2008. Essentially, the role of this variable is to exclude the effect of the variables $\mathrm{SD}_{5}(\pi)$, 'Global Savings Glut' and Debt $>75$ on nonGerman EMU countries over the period 1998-2008.

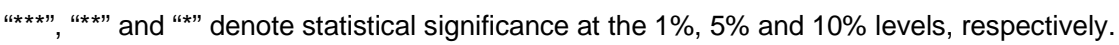

1. Bias correction initialised by Anderson and Hsiao estimator, with a level of accuracy up to $\mathrm{O}\left(\mathrm{N}^{-2} \mathrm{~T}^{-2}\right)$. The standard errors of the coefficients have been obtained with a bootstrap analysis, using 100 iterations.

Source: OECD calculations based on OECD Economic Outlook June 2011, IMF World Economic Outlook database, September 2011 data. 
Table 3. Summary statistics of the explanatory variables used in the regressions

\begin{tabular}{|c|c|c|c|c|}
\hline & $1980-95$ & $1996-99$ & $2000-08$ & 2010 \\
\hline \multicolumn{5}{|c|}{ STANDARD DEVIATION OF INFLATION ${ }^{1}$} \\
\hline \multicolumn{5}{|l|}{ G7 countries } \\
\hline Upper quartile & 1.99 & 0.90 & 0.75 & 0.99 \\
\hline Median & 1.45 & 0.65 & 0.60 & 0.85 \\
\hline Lower quartile & 1.07 & 0.45 & 0.44 & 0.66 \\
\hline \multicolumn{5}{|c|}{23 OECD countries ${ }^{2}$} \\
\hline Upper quartile & 2.57 & 1.39 & 1.31 & 1.53 \\
\hline Median & 1.66 & 0.94 & 0.71 & 1.12 \\
\hline Lower quartile & 1.18 & 0.59 & 0.48 & 0.81 \\
\hline \multicolumn{5}{|c|}{ Selected EMU countries ${ }^{3}$} \\
\hline Upper quartile & 2.26 & 1.70 & 0.97 & 1.13 \\
\hline Median & 1.51 & 1.18 & 0.63 & 1.01 \\
\hline Lower quartile & 1.14 & 0.80 & 0.47 & 0.68 \\
\hline \multicolumn{5}{|c|}{ SLOPE OF THE YIELD CURVE ${ }^{4}$} \\
\hline \multicolumn{5}{|l|}{ G7 countries } \\
\hline Upper quartile & 0.32 & -0.53 & -0.52 & -2.12 \\
\hline Median & -0.51 & -1.47 & -1.00 & -2.42 \\
\hline Lower quartile & -1.16 & -1.85 & -1.24 & -2.80 \\
\hline \multicolumn{5}{|c|}{23 OECD countries ${ }^{2}$} \\
\hline Upper quartile & 0.58 & -0.53 & -0.61 & -2.02 \\
\hline Median & -0.32 & -1.47 & -0.98 & -2.39 \\
\hline Lower quartile & -1.11 & -1.97 & -1.14 & -2.80 \\
\hline \multicolumn{5}{|c|}{ Selected EMU countries ${ }^{3}$} \\
\hline Upper quartile & 0.21 & -0.93 & -0.96 & -2.25 \\
\hline Median & -0.64 & -1.82 & -1.00 & -2.53 \\
\hline Lower quartile & -1.27 & -2.03 & -1.07 & -4.01 \\
\hline \multicolumn{5}{|c|}{ GLOBAL SAVINGS GLUT ${ }^{5}$} \\
\hline Mean & -0.06 & 0.07 & 0.68 & 0.79 \\
\hline
\end{tabular}

1. Five-year standard deviation of inflation based on the change in the GDP deflator.

2. Australia, Austria, Belgium, Canada, Denmark, Finland, France, Germany, Greece, Iceland, Ireland, Italy, Japan, Korea, The

Netherlands, New Zealand, Norway, Portugal, Spain, Sweden, Switzerland, United Kingdom, United States.

3. Austria, Belgium, Finland, France, Germany, Greece, Ireland, Italy, Netherlands, Portugal, Spain.

4. Difference between a 3-month short-term interest rate (usually the Treasury bill rate or similar) and the interest rate on 10year government bonds.

5. The current account surpluses of emerging Asian economies and major oil exporters expressed as a percentage of world GDP.

Source: OECD Economic Outlook June 2011, IMF World Economic Outlook database, September 2011, and OECD calculations, see Annex 1 for further details. 
ECO/WKP(2011)88

Table 4. The implied long-run effect of explanatory variables

Long-run effect of a unit change in the explanatory variable on the interest-rate-growth differential calculated on bias corrected LSDV estimates, percentage points

\begin{tabular}{|c|c|c|c|c|c|c|}
\hline & (1) & (2) & (3) & (4) & (5) & (6) \\
\hline $\mathrm{SD}_{5}(\pi)$ & 1.19 & 0.89 & 0.86 & 0.84 & 0.65 & 0.89 \\
\hline (irs -irl)-1 & 0.56 & 0.42 & 0.64 & 0.64 & 0.51 & 0.44 \\
\hline Global Savings Glut & - & -1.57 & -1.55 & -1.65 & -1.76 & -2.12 \\
\hline Debt $>75$ & - & - & 0.04 & 0.03 & 0.03 & 0.04 \\
\hline Dum2009-10*Debt >75 & - & - & - & 0.05 & - & - \\
\hline$\left(\left.i r\right|^{D E U}-g\right)_{-1}$ & - & - & - & - & 1.09 & 1.04 \\
\hline
\end{tabular}

Source: OECD calculations based on the results reported in Table 2. 


\section{BIBLIOGRAPHY}

Baltagi, B. and J. Griffin (1997), "Pooled Estimators vs their Heterogeneous Counterparts in the Context of Dynamic Demand for Gasoline”, Journal of Econometrics, Vol. 77.

Beffy, P., P. Ollivaud, P. Richardson and F. Sédillot (2006), "New OECD methods for supply-side and medium-term assessments: a capital services approach”, OECD Economics Department Working Paper, No.482.

Bernanke, B. (2005), “The Global Savings Glut and the US Current Account Deficit”, speech delivered at the Sandridge Lecture, Virginia Association of Economists, Richmond, Va, 10 March.

Bernanke, B. (2007), “The Global Imbalances: Recent Developments and Prospects”, speech delivered at the Bundesbank Lecture, Berlin, Germany, 11 September.

Bernanke, B., C. Bertaut, L. Pounder DeMarco and S. Kamin (2011), "International Capital Flows and the Return to Safe Assets in the United States, 2003-7”, Board of Governors of the Federal Reserve System, International Finance Discussion Papers, No.1014, February.

Bruno, G. (2005), “Approximating the Bias of the LSDV Estimator for Dynamic Unbalanced panel Data Models”, Economic Letters, Vol. 87.

Dobbs, R., et al. (2010), "Farewell to Cheap Capital? The Implications of Long-Term Shifts in Global Investment and Savings”, McKinsey Global Institute, December.

Égert, B. (2010), “Fiscal Policy Reaction to the Cycle in the OECD: Pro- or Counter-Cyclical?”, OECD Economics Department Working Papers, No.763.

Escolano, J., A. Shabunina and J .Woo (2011), "The Puzzle of Persistently Negative Interest Rate-Growth Differentials: Financial Repression or Income Catch-Up?”, IMF Working Paper No.11/260.

Haugh, D., P. Ollivaud and D. Turner (2009), "What Drives Sovereign Risk Premiums? An Analysis of Recent Evidence from the Euro Area”, OECD Economics Department Working Papers, No.718.

IMF (2011a), "Chapter 3 - Shocks to the baseline Fiscal Outlook”, IMF Fiscal Monitor, Washington, April.

IMF (2011b), “Appendix 4 -Stock-Flow Adjustments and their Determinants”, IMF Fiscal Monitor, Washington, September.

Laubach, T. (2009), "New Evidence on the Interest Rate Effects of Budget Deficits and Debt”, Journal of the European Economic Association, Vol.7.

Nickell, S. (1981), “Biases in Dynamic Models with Fixed Effects”. Econometrica, Vol.49. 
OECD (2010), “Chapter 4 -- Fiscal Consolidation: Requirements, Timing, Instruments and Institutional Arrangements”, OECD Economic Outlook, Vol.2010/2, Paris.

OECD (2011), “Chapter 4 -- Medium and Long-Term Developments: Challenges and Risks”, OECD Economic Outlook, No.89, May.

Reinhart, C. and K. Rogoff (2010), “Growth in a Time of Debt”, American Economic Review, Vol.100.

Wright, J. (2011), "Term Premia and Inflation Uncertainty: Empirical Evidence from an International Panel Dataset", American Economic Review, Vol.101. 


\section{ANNEX 1. DATA DESCRIPTION}

25. The data used in this paper cover 23 OECD member countries over the period 1980-2010. These countries were selected to maximise the time span of the panel dataset so that the maximum number of observations per variable would be 713 . However, due to the gaps in the data for some countries, particularly Greece and Iceland, the effective number of observations used in each regression is slightly lower. The exact country coverage of the variables is presented in Table A1.

26. Most of the data used in this paper are taken from the recently published OECD Economic Outlook No. 89 database, released in June 2011. Data used to construct the measure of the "global savings glut" are extracted from the IMF World Economic Outlook (WEO) database, released in September 2011.

27. Although various information on the variables used in the empirical analysis are provided in different sections of the main text, some extra details on the definition and construction of these variables are given below.

28. The simple model, corresponding to equation (1) in Table 2, includes the following variables:

- The interest-rate-growth differential as dependent variable defined as the difference between the levels of the interest rate on 10-year government bonds and nominal potential GDP growth. ${ }^{13}$ In the case of Norway, potential GDP estimates refer to the mainland economy, while in the case of Germany, a long time series for potential growth is explicitly constructed by splicing the growth rates of nominal potential GDP from 1991 on those of West Germany;

- Inflation volatility is measured as a five-year standard deviation of inflation, where the latter refers to the change in the GDP deflator;

- The slope of the yield curve is calculated as the difference between short-term interest rates (generally three-month Treasury bill rate) and long-term interest rates on 10-year Treasury bonds;

29. This model is subsequently extended with the inclusion of one or more of the following variables:

- A proxy measure of the global savings glut in equation (2), obtained by combining current account surpluses of Asian emerging economies and main oil exporting countries expressed as percentage of world GDP. Specifically, the two country groups selected from the WEO were "Developing Asia" and "Middle East and North Africa" (for more details on the groups composition see Table A2);

13. Potential growth is estimated using a production function approach as described in Beffy et al., 2006. 
- A variable measuring high government indebtedness is included in equation (3), and constructed for each country as the excess of the general government debt-to-GDP ratio when this share is above the threshold of $75 \%$ of GDP, and zero otherwise;

- A dummy variable taking value unity in the post-crisis years of 2009 and 2010 and zero elsewhere is used in equation (4) to construct the interaction term that allows for the testing of a differential effect from debt in the post-crisis years;

- A lagged variable measuring the differential between German long-term interest rates and other own-country growth in other EMU countries over the period 1998-2008 is considered in equation (5), Table 2;

- Finally, a dummy variable taking value unity for Euro area countries -- with the exception of Germany -- from 1998 to 2008 included and zero elsewhere, is used to exclude the influence of inflation volatility, global savings glut and debt variable for non-Germany EMU countries over that specific period from equation (6) in Table 2.

Table A1. Details on data availability

\begin{tabular}{lccl}
\hline Variable & start date & End date & Exceptions to the starting date \\
\hline $\begin{array}{l}\text { Interest rate - growth differential } \\
\text { (irl - g)t } \\
\text { dependent variable }\end{array}$ & 1980 & 2010 & $\begin{array}{l}\text { Portugal and New Zealand (1981), Switzerland (1982), Korea (1983), Greece } \\
(1994), \text { Iceland (1992) }\end{array}$ \\
\hline $\begin{array}{l}\text { Short-term interest rate minus } \\
\text { Long-term interest rate } \\
\text { (irs - irl)t }\end{array}$ & 1980 & 2010 & $\begin{array}{l}\text { Denmark (1981), Sweden (1983), Ireland (1985), Greece (1994), Iceland (1993), } \\
\text { Korea (1992) }\end{array}$ \\
\hline $\begin{array}{l}\text { Standard deviation of inflation } \\
\text { SD5 }(\pi) t\end{array}$ & 1980 & 2010 & Greece (1997) \\
\hline $\begin{array}{l}\text { Global savings glut } \\
\text { Debt 75 }\end{array}$ & 1980 & 2010 & - \\
\hline $\begin{array}{l}\text { German long-term interest rates - } \\
\text { own-country growth differential } \\
\text { (irl DEU- g)t } \\
\text { for non-German Euro area countries }\end{array}$ & 1980 & 2010 & Pustralia (1988), New Zealand (1993), Greece and Portugal (1995), Ireland, \\
\hline
\end{tabular}


Table A2. List of countries composing the different aggregates considered in the empirical analysis

\begin{tabular}{|c|c|}
\hline Country aggregate & Component countries \\
\hline OECD 23 & $\begin{array}{l}\text { Australia, Austria, Belgium, Canada, Denmark, Finland, France, Germany, Greece, Iceland, Ireland, Italy, } \\
\text { Japan, Korea, Netherlands, New Zealand, Norway, Portugal, Spain, Sweden, Switzerland, United Kingdom, } \\
\text { United States. }\end{array}$ \\
\hline G 7 & Canada, France, Germany, Italy, Japan, United Kingdom, United States. \\
\hline Selected EMU countries & Austria, Belgium, Finland, France, Greece, Ireland, Italy, The Netherlands, Portugal, Spain. \\
\hline Developing Asia & $\begin{array}{l}\text { Afghanistan, Bangladesh, Bhutan, Brunei, Cambodia, China, Fiji, India, Indonesia, Kiribati, Lao People's } \\
\text { Democratic Republic, Malaysia, Maldives, Myanmar, Nepal, Pakistan, Papua New Guinea, Philippines, } \\
\text { Samoa, Solomon Islands, Sri Lanka, Thailand, Democratic Republic of Timor-Leste, Tonga, Tuvalu, } \\
\text { Vanuatu, Vietnam. }\end{array}$ \\
\hline $\begin{array}{l}\text { Middle East and North } \\
\text { Africa }\end{array}$ & $\begin{array}{l}\text { Algeria, Bahrain, Djibouti, Egypt, Islamic Republic of Iran, Iraq, Jordan, Kuwait, Lebanon, Libya, Mauritania, } \\
\text { Morocco, Oman, Qatar, Saudi Arabia, Sudan, Syrian Arab Republic, Tunisia, United Arab Emirates, Republic } \\
\text { of Yemen. }\end{array}$ \\
\hline
\end{tabular}




\section{ANNEX 2. LEAST SQUARES PANEL ESTIMATION RESULTS}

30. Table A3 below reports the results of a least squares dynamic panel regression estimated with country fixed effects (with no correction for the presence of a lagged dependent variable) and Table A4 reports the long-run effects of the explanatory variables derived from those estimates. These tables can be compared with Tables 2 and 4, respectively, in the main paper, although the differences are generally quite small.

Table A3. Panel regression results explaining the interest-rate-growth differential for 23 OECD countries Sample 1980-2010, Dependent variable (irl - g), uncorrected LSDV estimates

\begin{tabular}{|c|c|c|c|c|c|c|}
\hline & (1) & (2) & (3) & (4) & (5) & (6) \\
\hline$(\mathrm{irl}-\mathrm{g})_{-1}$ & $0.6755^{\star \star \star}$ & $0.6270^{\star \star \star}$ & $0.6497 * \star \star$ & $0.6513^{\star \star \star}$ & $0.5880^{\star \star \star}$ & $0.5698^{\star \star \star}$ \\
\hline $\mathrm{SD}_{5}(\pi)$ & $0.3602^{\star \star \star}$ & $0.3082^{\star \star \star}$ & $0.2641^{\star \star \star}$ & $0.2561^{\star \star}$ & $0.2343^{\star \star \star}$ & $0.3482^{\star \star *}$ \\
\hline (irs -irl)-1 & $0.1906^{\star \star \star}$ & $0.1641^{\star \star \star}$ & $0.2330^{\star \star \star}$ & $0.2315^{\star \star \star}$ & $0.2209^{\star \star \star}$ & $0.2069^{\star \star \star}$ \\
\hline Global Savings Glut & - & $-0.6184^{\star * *}$ & $-0.5829^{\star \star *}$ & $-0.6084^{\star * *}$ & $-0.7675^{\star \star \star}$ & $-0.9272^{\star * *}$ \\
\hline Debt $>75$ & - & - & $0.0126^{* *}$ & 0.0063 & $0.0126^{* *}$ & $0.0179 * \star *$ \\
\hline Dum2009-10 * Debt >75 & - & - & - & $0.0184^{\star *}$ & - & - \\
\hline$\left(\left.\mathrm{irl}\right|^{\mathrm{DEU}}-\mathrm{g}\right)_{-1}$ & - & - & - & - & $0.3952^{\star \star \star}$ & $0.4041^{\star * *}$ \\
\hline Adjusted R-Squared & 0.57 & 0.58 & 0.6 & 0.61 & 0.61 & 0.62 \\
\hline S.E. of regression & 1.77 & 1.76 & 1.65 & 1.65 & 1.63 & 1.61 \\
\hline Schwarz criterion (BIC) & 4.2 & 4.19 & 4.09 & 4.1 & 4.08 & 4.05 \\
\hline Total panel observations & 654 & 654 & 604 & 604 & 604 & 604 \\
\hline Country fixed effects & yes & yes & yes & yes & yes & yes \\
\hline
\end{tabular}

Source: OECD calculations based on OECD Economic Outlook June 2011, IMF World Economic Outlook database, September 2011 data. 
Table A4. The implied long-run effect of explanatory variables

Long-run effect of a unit change in the explanatory variable on the interest-rate-growth differential based on uncorrected LSDV estimates, percentage points

\begin{tabular}{lcccccc}
\hline & $(\mathbf{1})$ & $\mathbf{( 2 )}$ & $\mathbf{( 3 )}$ & $\mathbf{( 4 )}$ & $\mathbf{( 5 )}$ & $\mathbf{( 6 )}$ \\
\hline $\mathrm{SD}_{5}(\mathbf{\pi})$ & 1.11 & 0.83 & 0.75 & 0.73 & 0.57 & 0.81 \\
(irs -irl).1 & 0.59 & 0.44 & 0.67 & 0.66 & 0.54 & 0.48 \\
Global Savings Glut & - & -1.66 & -1.66 & -1.75 & -1.86 & -2.16 \\
Debt $>75$ & - & - & 0.04 & 0.02 & 0.03 & 0.04 \\
Dum2009-10*Debt $>75$ & - & - & - & 0.05 & - & - \\
(irl & - & - & - & - & 0.96 & 0.94 \\
\hline
\end{tabular}

Source: OECD calculations based on the results reported in Table A3. 


\section{WORKING PAPERS}

The full series of Economics Department Working Papers can be consulted at www.oecd.org/eco/workingpapers/

918. Reassessing the NAIRUs after the crisis

(December 2011) by Stéphanie Guichard and Elena Rusticelli

917. Employment protection legislation and plant-level productivity in India

(December 2011) by Sean Dougherty, Verónica Frisancho Robles and Kala Krishna

916. Systemically important banks and capital regulation challenge

(December 2011) by Patrick Slovik

915. Improving educational outcomes in Slovenia

(December 2011) by Mehmet Eris

914. Addressing challenges in the energy sector in Israel

(December 2011) by Philip Hemmings

913. Issues in private sector finance in Israel

(December 2011) by Philip Hemmings

912. How to improve the economic policy framework for the housing market in Israel

(December 2011) by Philip Hemmings

911. Fiscal Prospects and Reforms in India

(December 2011) by Richard Herd, Sam Hill and Vincent Koen

910. Structural reforms to reduce unemployment and restore competitiveness in Ireland

(December 2011) by Álvaro Pina

909. Getting back on track: restoring fiscal sustainability in Ireland

(December 2011) by David Haugh

908. A welfare analysis of climate change mitigation policies

(November 2011) by Alain de Serres and Fabrice Murtin

907. Overcoming the banking crisis in Ireland

(November 2011) by Muge Adalet McGowan

906. Macroeconomic and structural policies to further stabilise the Mexican economy

(November 2011) by Cyrille Schwellnus

905. Reaping the benefits of a transition to greener growth in Slovakia

(November 2011) by Caroline Klein

904 Fiscal reform for a stronger fairer and cleaner Mexican economy

(October 2011) by Nicola Brandt and Rodrigo Paillacar

903 The demand for safe assets in emerging economies and global unbalances: new empirical evidence (October 2011) by Rudiger Ahrend and Cyrille Schwellnus 
902. Drivers of systemic banking crises: the role of bank-balance-sheet contagion and financial account structure

(October 2011) by Rudiger Ahrend and Antoine Goujard

901 Explaining the appreciation of the Brazilian Real

(October 2011) by Annabelle Mourougane

$900 \quad$ Raising investment in Brazil

(October 2011) by Jens Arnold

899 Refining macroeconomic policies to sustain growth in Brazil

(October 2011) by Annabelle Mourougane

898. Promoting infrastructure development in Brazil

(October 2011) by Annabelle Mourougane and Mauro Pisu

897. Austria: public sector inefficiencies have become less affordable

(October 2011) by Karin Fischer, Rauf Gönenç and Robert Price

896. Informality in Mexico

(September 2011) by Nicola Brandt

895. Reforming Austria's highly regarded but costly health system

(September 2011) by Rauf Gönenç, Maria. M. Hofmarcher, Andreas Wörgötter

894 Greener growth in the Belgian federation

(September 2011) by Tomasz Koźluk

893. Green growth and climate change policies in New Zealand

(September 2011) by Alexandra Bibbee

892. Has deregulation increased investment in infrastructure? Firm-level evidence from OECD countries

(September 2011) by Sónia Araújo

891. Ensuring a Sustainable and Efficient Fishery in Iceland

(September 2011) by Gunnar Haraldsson and David Carey

890. Japan's New Growth Strategy to create demand and Jobs

(September 2011) by Randall S. Jones and Byungseo Yoo

889. Labour market reforms in Japan to improve growth and equity

(September 2011) by Randall S. Jones and Satoshi Urasawa

888. Education reform in Japan

(September 2011) by Randall S. Jones

887. The Political Economy of Climate Change Mitigation Policies: How to Build a Constituency to Address Global Warming?

(August 2011) by Alain de Serres, John Llewellyn and Preston Llewellyn 